\title{
Preliminary development of a system to manipulate and monitoring a flexible manufacturing cell
}

\section{Desarrollo preliminar de un sistema para la manipulación y monitoreo de una celda de manufactura flexible}

\author{
MUÑOZ-MATA, José Lorenzo†*, ROJAS-GARNICA, Juan Carlos, CERVANTES-DE LA ROSA, \\ Juan Pedro and OCOTITLA-MUÑOZ, Alma Delia
}

Universidad Tecnológica de Puebla

ID $1^{\text {st }}$ Author: José Lorenzo, Muñoz-Mata / ORC ID: 0000-0001-7813-5579, CVU CONACYT ID: 177117

ID $1^{\text {st }}$ Co-author: Juan Carlos, Rojas-Garnica / ORC ID: 0000-0002-2261-587X, CVU CONACYT ID: 66417

ID $2^{\text {nd }}$ Co-author: Juan Pedro, Cervantes-De La Rosa / ORC ID: 0000-000I-6634-2018

ID $3^{\text {rd }}$ Co-author: Alma Delia, Ocotitla-Muñoz / ORC ID: 0000-0002-3266-3226, CVU CONACYT ID: 851782

\begin{abstract}
Flexible Manufacturing Systems (FMS) are more commonly used in modern industry due to the benefits offered, such as: low-cost production, easy adaptation to elaborate different products according to the client necessities. A Flexible Manufacturing Cell (FMC) has two or three workstations; moreover, a system to control and manipulate de process. Industrial communications protocols are used to communicate workstations of a FMC, such as: Profibus, Ethernet, Device Net, etc. For the case of not have such protocol to communicate devices, due to an incompatibility between protocols, an alternative solution has been implemented in order to perform the same function. In this work, is presented the obtained results of a preliminary development of a system capable to manipulate and monitoring a flexible manufacturing cell using a communication card using a microcontroller to communicate a HAAS VF2 machining center and a FANUC robot M6iB. Moreover, an user interface is developed using LabVIEW with a web cam, which communicates with the microcontroller via RS-232, with the capability of monitoring the system via internet.
\end{abstract}

Flexible Manufacturing System, Microcontroller, LabVIEW

\section{Resumen}

Los sistemas de manufactura flexible (SMF) son cada vez más utilizados por la industria moderna debido a las prestaciones que estos ofrecen, tales como: producción a bajo costo, fácil adaptación para elaborar distintos productos de acuerdo a las necesidades del cliente. Una Celda de manufactura flexible (CMF) consiste de dos o tres estaciones de trabajo; además de un sistema que controle y manipule el proceso. Para comunicar las estaciones que conforman un CMF se utilizan protocolos de comunicación industrial tales como: Profibus, Ethernet, Device Net, etc. En el caso de no contar con estos protocolos para la comunicación entre dispositivos, debido a una incompatibilidad entre protocolos, se debe desarrollar una solución alterna que realice esta misma función. En este trabajo, se muestran los resultados obtenidos del desarrollo preliminar de un sistema capaz de manipular y monitorear una celda de manufactura flexible utilizando una tarjeta de comunicación con un microcontrolador para comunicar un centro de maquinado HAAS VF2 y un Robot FANUC M6iB. Además, se desarrolla una interfaz de usuario usando LabVIEW, esta se comunica con la tarjeta vía RS-232 para el envío bidireccional de información y una cámara para monitoreo y supervisión del sistema.

Sistema de Manufactura Flexible, Microcontrolador, LabVIEW

Citation: MUÑOZ-MATA, José Lorenzo, ROJAS-GARNICA, Juan Carlos, CERVANTES-DE LA ROSA, Juan Pedro and OCOTITLA-MUÑOZ, Alma Delia. Preliminary development of a system to manipulate and monitoring a flexible manufacturing cell. Journal of Technological Operations. 2021. 5-15: 18-25

\footnotetext{
* Author Correspondence (e-mail: jose.munoz@utpuebla.edu.mx)

$\uparrow$ Researcher contributing as first author.
} 


\section{Introduction}

In the context of the so-called fourth industrial revolution or industry 4.0, which is in pursuit to establish a fully automated industry through the digitization of manufacturing processes (Roblek et al. 2016) where flexible manufacturing systems are linked locally and globally, the creation of communication interfaces highly efficient and with low cost are of great relevance. The key characteristics, on which Industry 4.0 bases its advance, are as follows (Atik y Ünlü 2019):

\section{Digitization of production and information systems. \\ 2. Automation of systems. \\ 3. Automatic data exchange.}

With the use of digital information management, it is possible to monitoring constantly the necessities of a given market, which allows industries, to know the necessary adjustments that must be made in the manufacturing systems in very short times, but this leads to the necessity to be as flexible as possible to minimize the cost of readjustment to the new market necessities. This flexibility, which in principle can be applied to both manual and automatic systems (Kang 2016), consists of the capability to identify and distinguish between the different parts or products processed by the system and, to respond immediately to market variations, it must have high changing rates in operating instructions and physical configuration, which is best achieved in automated low-element systems (Brettel et. al 2015).

Flexible Manufacturing Systems (FMS) are classified by the level of flexibility and the number of machines or workstations (Singh 2018). If the system has a workstation, it is called a single machine cell (SMC). If it contains two to three workstations such as a numerical control machine, a robot, and a storage system, it is called a flexible manufacturing cell. (FMC) (Hernández 2012). For the local or global communications of an FMS, there are a series of commercial protocols such as Device Net, Ethernet, Profibus, Fieldbus, among others (Rodríguez. 2013). However, in situations of certain complexity and in which such protocols are not available, it is important to design and implement alternative resources of communication since they are too expensive to implement. (Guerrero et al. 2009).
Therefore, this work shows a communication interface proposal to implement an FMC as infrastructure development for academic and teaching purposes within the Universidad Tecnológica de Puebla. This proposal pursuits the implementation of the communication between the elements of the cell, as well as the monitoring and reconfiguration of the cell data, remotely, as a tool of the industry 4.0, which gives to the CMF the possibility to readjust according to the information provided by a specific market situation.

The proposed system was implemented using a microcontroller configured as a PLC, with inputs and outputs necessary to communicate a FANUC M6iB robot with a HAAS VF2 machining center, using simple signal communication, emphasizing the inherent advantage of being a device much cheaper to implement than a PLC with a certain commercial communication protocol.

Given the current circumstances of the health emergency generated by the SARS COV 2 virus, the physical implementation of the designed system was not possible. Therefore, the results shown in this work are only from a simulation implemented of the communication card, where the input and output data are obtained, as well as the communication with the computer for the manipulation and visualization of the input and output registers of the system, and the monitoring through a web camera and published on an internet page. However, all the documentary material necessary for its prompt physical completion was developed once conditions allow access to the facilities.

\section{Experimental Setup.}

Figure 1 shows the block diagram of the implemented system. It can be observed the elements necessary for the development of the system.

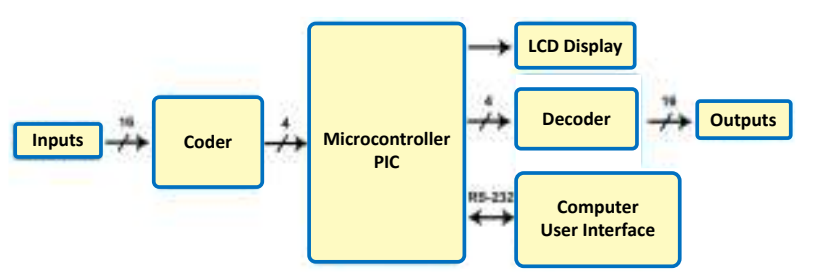

Figure 1 Block diagram of the implemented system Source: Own 
As can be observed in Figure 1, for the implementation of the communication card between the machining center and the robot, a Microchip 16F877A microcontroller was used (Microchip 2006). On the other hand, in order to scale the number of inputs and outputs of the card, encoders and decoders were used respectively, achieving a number of 16-bit for inputs and outputs. Furthermore, the RS-232 communication module (Angulo et al. 2004) of the microcontroller was used to communicate the card with a computer, where a user interface was developed with the LabVIEW virtual instrumentation software (Sumathi et al. 2007), in such a way the inputs and outputs of the communication card can be manipulated, and the workstations can be manipulated from a computer. In order to monitor the process from a computer on the same internal network, a web camera is used, which is integrated into the same interface, where it is possible to observe the manufacturing process that is currently running.

\subsection{Communications Card}

The communication card was designed to implement the communication between the robot and the machining center and to perform the sequence of operation of the process from its inputs and outputs; moreover, it can be operated manually to test each stage of the process. The card has 16-bit input registers that can be integrated into the process sequence. Due to the number of pins available in the microcontroller, it was necessary to use encoders with license plate $74 \mathrm{HC} 147$ in order to be able to scale the number of bits and obtain a 4-bit code to reduce the number of physical lines between the inputs and the device as shown in Figure 2.

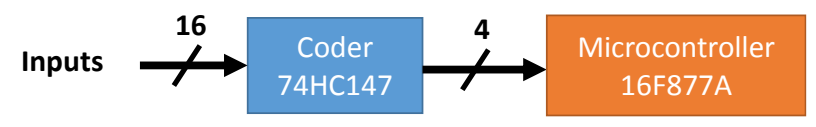

Figure 2 Coder configuration for the input signal acquisitions

Source: Own

In addition, Figure 3 shows the configuration for the generation of output data. As can be observed, there are 16 output bits, in the same way a decoder with license plate CD4514 was used; therefore, 16 bits can be generated from a 4-bit input code.

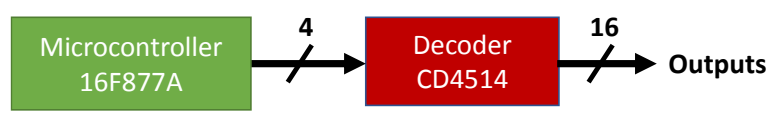

Figure 3 Decoder configuration to generate the output signals

Source: Own

Having sufficient general-purpose pins, it will allow to integrate an additional workstation if it's necessary to escalate the system, as well as additional elements such as, sensor, actuators required for the functional process of an FMC.

The controller R-Ji3B will be used to communicate with the FANUC robot, which has five horizontal ports ABU05A. These ports are dedicated to connect specific modules of communication. In this case, to perform the communication with the FANUC robot, input module (AID32E1) and the output module (AOD32D1) were used. (FANUC Automation 2000). Therefore, it is necessary to isolate the communication card and the robot connection modules, since the modules work at industrial voltage level of $24 \mathrm{~V}$, thus, an adjustment must be considered since the card handles voltage level of $5 \mathrm{~V}$. Therefore, an optocoupler $4 \mathrm{~N} 26$ was used for this purpose. The developed circuit for the input signal acquisition is shown in Figure 4.

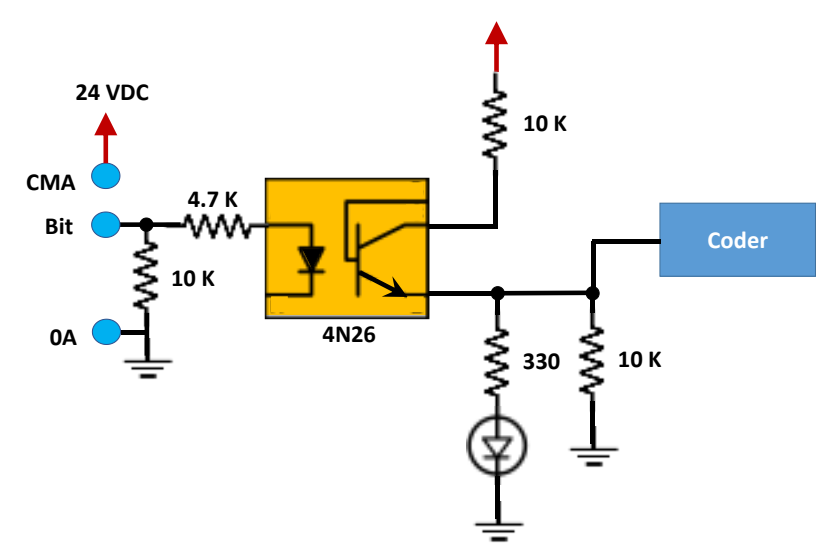

Figure 4 Isolation and voltage level conversion circuit for data acquisition Source: Own

This simple circuit performs the isolation and voltage level conversion from the input of the robot module and the card. This circuit must be implemented for each of the 16-bits input, which are connected to the encoders. 
On the other hand, to isolate the card from the outputs of the robot module and convert the voltage levels to generate the output signals and send them to the robot, optocouplers are used. The corresponding circuit is shown in Figure 5.

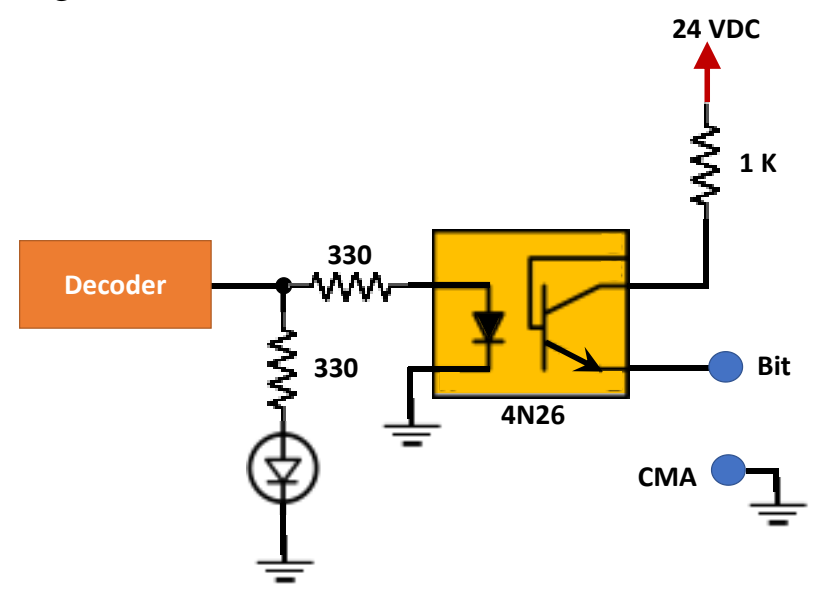

Figure 5 Isolation and voltage level conversion circuit for data generation

Source: Own

It is important to mention that this circuit it must be replicated for each one of the output bits generated from the communication card.

The communication with the machining center will be performed using a parallel connection with the machining control panel, to active the machining process as well to open and close the machine doors. In addition, a mechanical press will be used to clamping the material, which it will be activated electrically from the output signal of the communication card using relays to isolate the $\mathrm{CNC}$ for its protection.

The central part of the communication card was performed using a microcontroller, a firmware was developed using the CCS compiler (Trejo 2009). Such algorithm has the ability to acquire the input signals and generate the output signals to integrate both the machining center and the robot in a certain sequence by displaying the information on an LCD. In addition, a RS232 communication module (Angulo et al. 2004) was used to communicate the card with the computer and establish the visualization of the activated inputs and outputs, and to manipulate such signals. Figure 6 shows the flow chart corresponding to the firmware developed within the microcontroller.
To manipulate the outputs of the electronic card, the system has the capability to detect whether the output is activated from an input data on the card or from the computer. Therefore, if a data is received, an output will be activated, and the data received will be displayed on the LCD display. For the case of no data is being received, the data sending is activated pressing one of the 16 buttons, each button will send a different binary data ( 0 to 15 ), then, an output signal will be activated and sent. Finally, the data will be visualized in the LCD.

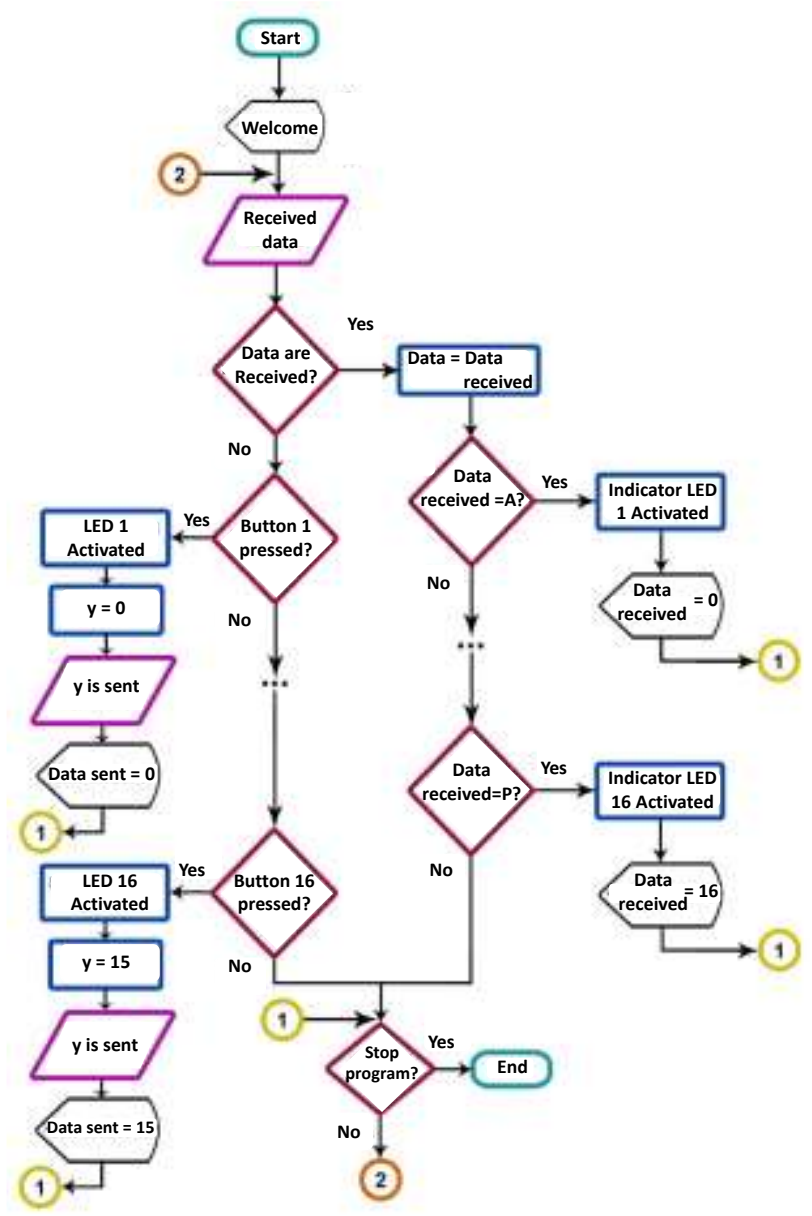

Figure 6 Flow chart of the firmware developed Source: Own

\subsection{User Interface}

The purpose of the development of an user interface is to be able of monitoring and manipulate the system from a computer, without the necessity of being physically at the process to perform a determined sequence of certain activities or simply to be able to activate manually a system test from a computer. 
Such user interface was developed using the virtual instrumentation software LabVIEW, which establish the communication with the electronic card via RS-232 protocol using the Virtual Instruments Software Architecture (VISA) (National Instruments 2001) for reading and writing data. The software has the capability to manipulate the inputs, that is, write data to the card from the computer. Additionally, the software read and display on the front panel which outputs are being activated depending on the sequence of the process that is being executed. The front panel of the developed software is shown in Figure 7.

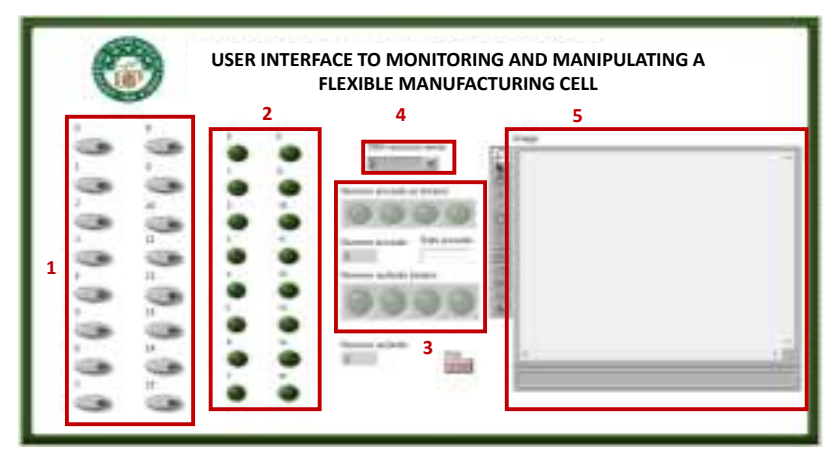

Figure 7 Front panel of the developed user interface Source: Own

In Table 1, are shown the elements of the user interface according with the numeration in Figure7.

\begin{tabular}{|c|l|}
\hline No. & \multicolumn{2}{|c|}{ Description } \\
\hline 1 & $\begin{array}{l}\text { Buttons for writing data to the communication } \\
\text { card to manipulate its outputs. }\end{array}$ \\
\hline 2 & LED's indicating the data read. \\
\hline 3 & $\begin{array}{l}\text { Data code read }(0 \text { to } 15) \text { from the } \\
\text { communication card. }\end{array}$ \\
\hline 4 & RS-232 serial communication port selector. \\
\hline 5 & $\begin{array}{l}\text { Image indicator captured by the camera for } \\
\text { visualization and monitoring of the process. }\end{array}$ \\
\hline
\end{tabular}

Table 1 Description of components of the user interface front panel

Source: Own

The flow chart of the algorithm used to implement the software is shown in Figure 8. To establish serial communication, the port must be selected, and the serial communication parameters are configured (transfer speed, bits to be used, etc.). When a data is received, it will be the first data evaluated if such is a 4-bit register since it is the expected length at the reception of data and decoded to represent the 16 outputs in binary code according to the output activated; therefore, the data received is shown to the user, activating the corresponding LED indicators representing the received data.
If the bit length of the code is greater than 4 bits, then the information received will not be registered. To send data to the communication interface, one of the 16 buttons on the front panel must be pressed, each button sends a different data to activate different outputs of the communication interface card.

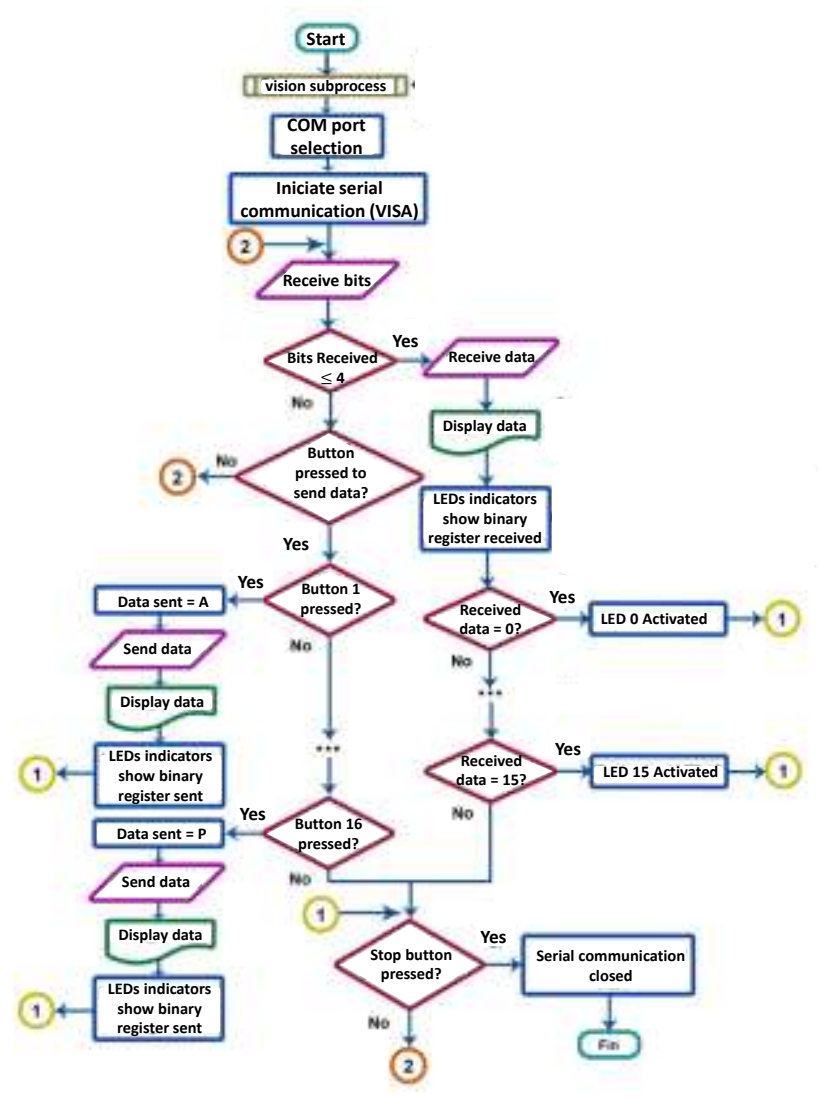

Figure 8 Flow chart of the developed software Source: Own

On the other hand, to perform the visualization and monitoring of the process through a camera the LabVIEW vision module was used, which is a set of controllers and utilities used to acquire, display and store images from a wide range of camera types. Therefore, for this process, the camera is configured to acquire 25 frames per second (fps). It is important to mention that the implemented algorithm is executed in parallel with the acquisition system with the communication card to integrate the complete system in a unique virtual instrument.

Finally, to perform the simulation, the virtual serial ports emulator (VSPE) was used, which is responsible for generating the corresponding virtual serial ports to be able to integrate the entire circuit of the communications card implemented in the electronic design automation software Proteus Design Suite (Trejo 2009). 
Using the libraries offered by this software and the serial port emulator, it is possible to simulate and communicate via RS232 to the communication card with the computer to verify the correct operation of the designed system. This is due to the fact that it was not possible to develop the physical implementation of the system given the current sanitary circumstances.

\section{Results}

To verify the correct operation of the communication card, the implementation of the circuit for its simulation was developed. In Figure 9 is shown the implemented circuit.

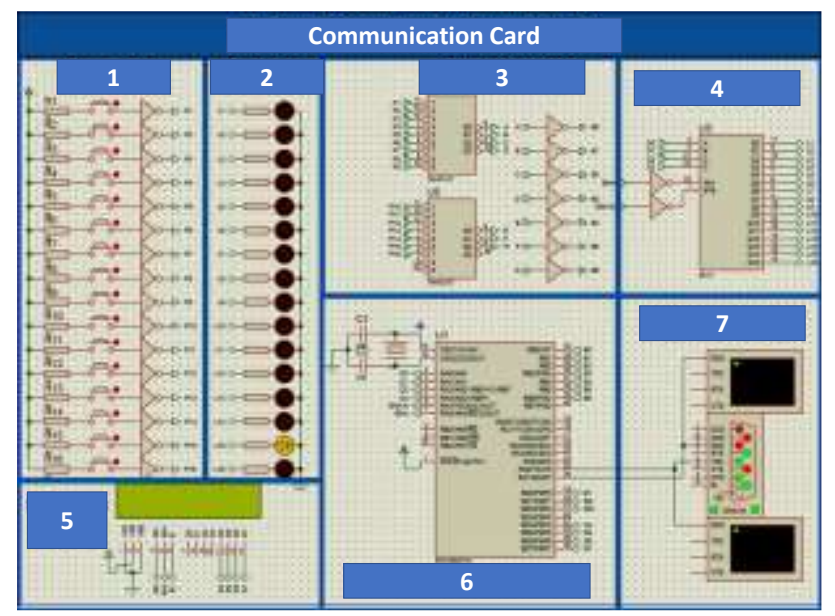

Figure 9 Circuit of the communication card implemented Source: Own

In Table 2, are shown the components of the developed circuit.

\begin{tabular}{|c|l|}
\hline \multicolumn{1}{|c|}{ No. } & \multicolumn{1}{|c|}{ Description } \\
\hline 1 & Input buttons \\
\hline 2 & Output indicator LEDs. \\
\hline 3 & Coders \\
\hline 4 & Decoders \\
\hline 5 & LCD 2x16 Display. \\
\hline 6 & Microcontroller. \\
\hline 7 & RS-232 COM port and virtual terminals. \\
\hline
\end{tabular}

Table 2 Description of elements of the communication card

Source: Own

Initially, the corresponding simulations of the circuit were executed to verify that the circuit performs the functions correctly according to the proposed design. In addition, virtual terminals were placed where it could be observed that the microcontroller actually sends the 4-bit code, via RS-232, corresponding to the activated input, observing satisfactory results.
Once the operation of the electronic section was tested, the complete system was integrated, where the serial communication of the implemented card with the developed user interface is established. This test consists of sending input data from the communication card, which must be encoded at 4 bits and sent to the microcontroller, which must activate the output LED corresponding to the input bit pressed.

On the other hand, the 4-bit encoded data must be sent via serial to the computer, according to the algorithm, such register must be decoded and just like the output of the card; however, in this case in the panel of the interface, the indicator LED corresponding to the input bit pressed must be activated. Figure 10 shows the simulation of the integrated system.

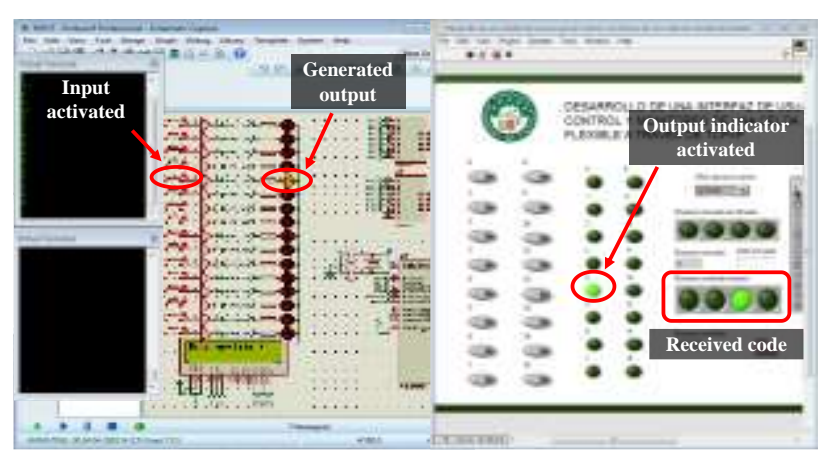

Figure 10 Simulation of experimental tests of the integrated system (writing to the computer) Source: Own

As can be observed, an input has been generated in bit 5 of the 16 available, activating the LED number 5 of the output register. Moreover, it can be observed that in the interface which code is received form the communication card. And activate the LED number 5 indicator of the 16 available. Therefore, for the case of the writing process to the computer, it was observed that the system works properly.

Subsequently, a test was performed to verify the data reading from the card. In this case, it consists of manipulating the system from the user interface to the communication card that eventually will manipulate both the robot and the machining center. 


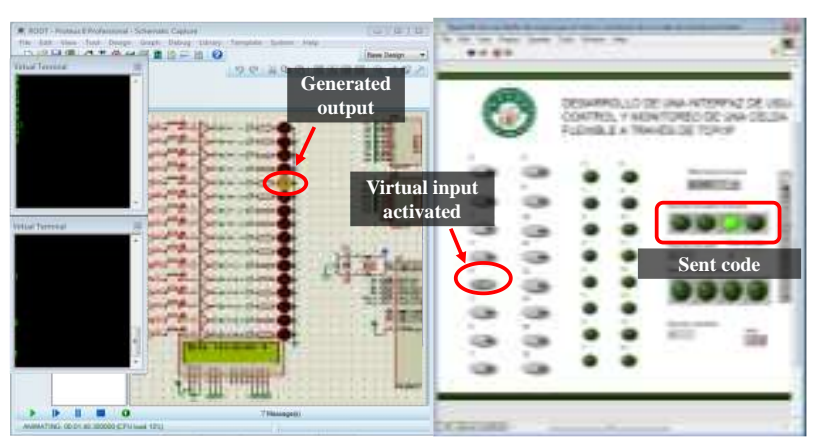

Figure 11 Simulation of experimental tests of the integrated system (read from the computer)

Source: Own

In Figure 11, it can be observed the simulation of the integrated system, where an input data (bit 5) is generated from the interface, generating a 4-bit code that is sent to the communication card; therefore, such register is read by the card. As is shown, the results obtained were satisfactory.

Finally, the interface was published on the internet using the LabVIEW Web Publishing tool. For our purposes, the monitoring mode was used, where the working process can be remotely observed. Figure 12 shows the front panel publication of the developed interface.

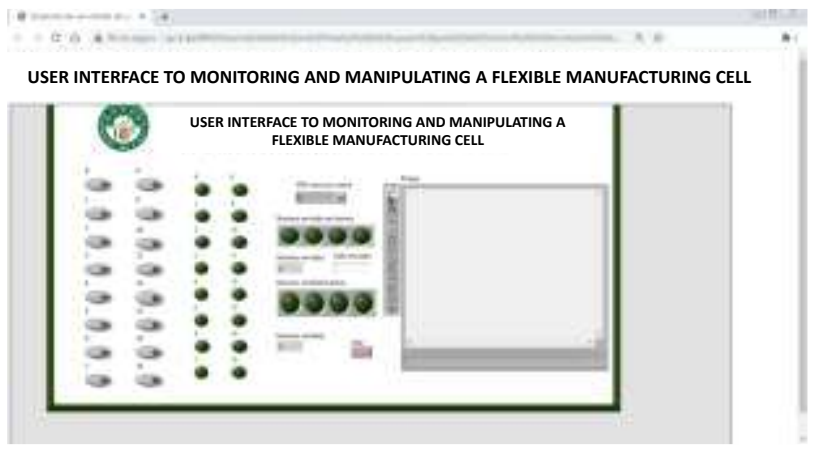

Figure 12 Publication on the web of the user interface front panel for monitoring

Source: Own

The corresponding tests were performed, can be observed that it has been developed a system with the capability to control a flexible manufacturing cell through the development of a card that communicates a robot and a machining center to execute the sequence of a determined process. In addition, this system can activate such sequence from a computer using a user interface, which it is possible to activate inputs and outputs from the card manually. To monitoring the system, a camera has been integrated to be able to observe the process.
Finally, the interface developed via internet was published to monitor the process, in order to observe and know the status of the process remotely and become a tool of industry 4.0.

\section{Acknowledgments}

To the Universidad Tecnológica de Puebla for the facilities provided for the integration of the Flexible Manufacturing Cell.

\section{Conclusions}

A system to control a flexible manufacturing cell which can perform a certain process communicating workstations such as an industrial robot and a machining center has been developed. Since there is no protocol compatibility, the communication was performed through the development of a communication card between the workstations execute a sequence of a certain process. Moreover, this system can activate such sequence from a computer using a user interface, where it is also possible to activate inputs and outputs of the card manually from the computer. To monitor the system, a camera has been integrated to the system to observe the process.

\section{Future work.}

Given the current health circumstances, this project, was only implemented at a simulation level. The physical implementation of the project is at construction level. In order to install and execute the system, it is being implemented this work using the corresponding elements for the integration of a Flexible Manufacturing Cell, which is the future work to be developed.

\section{References}

Alegría Martínez, M. A. (2021). Diseño automatizado de metamateriales mecánicos blandos mediante evolución artificial en un ambiente simulado.

A. Singh, J. Singh, M. Ali, (2018). Some Control Strategies in a Flexible Manufacturing SystemA Simulation Perspective. International Journal of Applied Engineering Research, 7, 5296-5303. 
Carpena Tafur, D. A., \& Muñoz Herrera, M. R. (2021). Propuesta de aplicación de un sistema pull y celda de manufactura flexible en el proceso de acabados de las PYME's del sector textil exportador de prendas de vestir tipo punto de algodón para incrementar su competitividad.

GE Fanuc Automation Europe (2000) I/O Unit model a connection maintenance manual [Manual], Featherstone Road http://ucc.colorado.edu/fanuc/61813e.pdf

García Trejo, E. (2009). Compilador C CCS y Simulador Proteus para Microcontroladores PIC ( $2^{\mathrm{a}}$ ed.). Ciudad de México, México: Alfaomega.

G. Hernández (2012). Fundamentos de Control Inteligente de La Manufactura Flexible ( $1^{\mathrm{a}}$ ed.). España: Eae Editorial Academia Española.

H. Atika, F. Ünlü. (2019) The Measurement of Industry 4.0 Performance through Industry 4.0. 3rd World Conference on Technology, Innovation and Entrepreneurship (WOCTINE). Elsevier. 852-860.

H. S. Kang, J. Y. Lee, S. S. Choi, H. Kim. J. H. Park, J. Y. Son, B. H. Kim, S. D. Noh, (2016). Smart Manufacturing: Past Research, Present Findings, and Future Directions. International Journal of Precision Engineering and Manufacturing-Green Technology, 3(1), 111128.

J. Angulo, S. Romero, I. Angulo (2004). Microcontroladores PIC, Diseño práctico de Aplicaciones Segunda Parte (1a ed.). Madrid, España; Mc Graw Hill.

Lupi, O. D., Zaradnik, I. J., Soares, H. A., Panza, G., Domínguez, F., Bernis, A., ... \& Turconi, D. H. (2021). Desarrollo de sistemas para la medición de radiaciones ionizantes.

M. Brettel, M. Klein, N. Friederichsen. (2015). The relevance of manufacturing flexibility in the context of Industrie 4.0. 48th CIRP Conference on Manufacturing Systems-CIRP CMS 2015. Elsevier. 105-110.

Mamani Zela, T. R. (2021). Aplicación de herramientas Lean Construction para el mejoramiento de productividad en proyectos de saneamiento básico rural ejecutadas por la empresa SICMA SAC en la región de Puno durante los periodos 2017-2019.
Microchip. (2006, 1 enero). PIC18F2455/2550/ 4455/4550 Data Sheet [Datasheet]. Recuperado 10 octubre, 2017, de https://ww1.microchip.com /downloads/en/devicedoc/39632c.pdf

National Instruments Corporate Headquarters (2001). NI VISA User Manual. https://www.ni.com/pdf/manuals/370423a.pdf

Ortega Quiñonez, L. H., \& Silva García, N. (2021). Sistema de navegación autónoma en robot móvil tipo oruga para apoyo en tareas de siembra en campos caficultores.

P. Rodríguez (2013). Sistemas SCADA (3a ed.). Ciudad de México, México: AlfaomegaMarcombo.

S. Sumathi, P. Surekha (2007). LabVIEW based Advanced Instrumentation Systems (1a ed.). Ney York, USA; Springer.

V. Guerrero, L. Martínez, R. Yuste (2009). Comunicaciones Industriales (1a ed.). Ciudad de México, México: Alfaomega-Marcombo.

V. Roblek, M. Meško, A. Krapež. (2016). A Complex View of Industry 4.0. Sage Open Volume 6 Issue 2. 1-11. 